\title{
Fruit Farming and Tribal Autonomy in Oklahoma's Green Country: The Native American Small Business Model
}

\author{
Janet Altamirano \\ Texas A \& M - Kingsville \\ 2227 Woodstream Blvd. Sugar Land, TX 77479
}

\begin{abstract}
An exploration of a Native American business model used by the Cherokee and Muscogee (Creek) Indian tribes.
\end{abstract}

Key words: Economic development, Native American economy

\section{INTRODUCTION}

Oklahoma's Green Country, an area of land with rolling hills, major rivers and dense trees located in the foothills of the Ozark Mountains, became home to tribal peoples relocated from the southeastern United States during the nineteenth century. Two large tribes, the Cherokee Nation and the Muscogee (Creek) Nation, had been neighbors in the location of the current state of Alabama and became subsequent neighbors in Indian Territory, prior to it becoming the current state of Oklahoma. Fruit farming, especially strawberry and peach production, dominate in the fertile soil created by major rivers that flow in a southeasterly direction toward the Mississippi River. Fruit farming was not only a way to increase diversity in crops, beyond the traditional ones of wheat and cattle, but also bridge horticulture with a Native American small business model, and the pursuit of profit, which is required in a modern economy. Even though casino gaming generates much more cash flow, farming and crafting continue to lead as choices of employment for individual Native Americans in Oklahoma. A Native American small business model that enhances communal ties and provides employment opportunities in traditional ways is sustaining tribal culture and autonomy.

Small businesses, with fewer than 500 employees, made up 99.7 percent of all employer firms in 2008 and when owned by Native American tribes are interesting models of how corporate businesses can be owned and managed by a small related group with a shared culture for their mutual benefit (Bodley, 2017). Working with others who share a common cultural heritage and language can not only benefit the tribal members by providing them with personal income but also be an important source of economic development for small towns. While statistically many of Oklahoma's small towns have higher high school graduation rates than its larger cities (www.oklahomawatch.org/2016/02/15/graduation-rates-by-school-district/), economic development in small towns is often challenged by the lack of high paying jobs and the emigration of ambitious youth towards greater opportunity.

In the nineteenth century, the United States territory was tripled by a policy of military conquest that reduced the population of Native Americans by 95 percent and an economy that favored increased production and faster distribution of goods (Bodley, 2017). When Oklahoma became a state, tribal power and land ownership was significantly reduced through legislative acts, including the Dawes Allotment Act, that allotted land to individual Native American members. Federal officials envisioned for Indian Territory to be an expanse of active farms 
and ranches, dotted with commercial centers, a significant change from the traditional extended family enclaves with collective labor common in foraging societies (Cooper, 2016).

Franklin D. Roosevelt and John Collier, the appointed commissioner of Indian affairs, completely reversed old policies allowing for the sale of Indian land by implementing the 1934 Indian Reorganization Act that among other things allowed tribes to control their money, run as corporation and manage communal property (Debo, 1970). Following the 1934 Act, the Oklahoma Indian Welfare Act permitted tribeless Indians in Oklahoma to organize as corporations and form co-operatives and access money from a revolving loan fund of two million dollars (Debo, 1970). John Collier was an advocate for Native American culture and protection and when speaking of the change in policy he believed at the minimum, the tribe is a legally recognized holding corporation - a holder of property and a holder of tangible rights granted by treaty or statute (Debo, 1970). The sale of Indian land at the turn of the twentieth century had taken power away from tribal leaders and forced a once foraging culture into the small-scale farming allowable on an allotted parcel of land. While John Collier's use of the word "corporation" does not use or imply the word "profit," ownership of land is a basis for generating wealth in a modern economy. Debo's reference to tribeless Indians emphasizes how the loss of tribal land first began to reverse with the formation of farming co-operatives which generate a larger opportunity from small parcels of land.

\section{STILWELL STRAWBERRIES}

Good soil and a long growing season create conditions in Oklahoma that are favorable to fruit farming, especially strawberries and peaches. Stilwell, Oklahoma, with a population that is 48 percent Cherokee (www.census.gov/prod/cen2010/briefs/c2010br-10) has an economy that is dependent upon agriculture and since the Great Depression has been a successful area for growing strawberries. The Oklahoma Indian Welfare Act, subsequent loan money, fertile soil and a nearby railroad junction served agriculture well. For the Cherokee who lived on small allotments held in trust by the federal government, strawberries were an ideal crop. Strawberries grow well in shallow soil and require little acreage, spread on a runner system near the surface and thrive in Oklahoma's short hot summer. For a hundred years, Cherokee women in the foothills of the Ozarks had been harvesting buckbrush runners to dry and weave into buckbrush baskets (Cooper, 2016). Plant knowledge would serve the Cherokee well as they developed strawberry agriculture in a modern economy. In 1937, the revolving loan fund to Oklahoma Indians became available and by 1949, 150 families were raising strawberries on forty acres in the business model of a co-operative after accessing a loan (Debo, 1970). The landed property became the basis of this collective economy, grew instead of shrinking and in Oklahoma, the strawberry business succeeded with accessible capital, Indian labor, and selfhelp from contented people living on their land (Debo, 1970).

The economic anthropologist, Rhoda Halperin, who did fieldwork in rural Kentucky, describes a familial economy, in which the goal is not to accumulate wealth, but to make ends meet through family networks engaging in economic activities (1994). These economic activities include a combination of capitalistic and pre-capitalistic ways like farming kitchen gardens, buying and selling in flea markets, and wage labor (1994). Rural Appalachians make ends meet while controlling their own labor and not becoming dependent on capitalism (1994). Farming and crafting in a Native American business model strengthens family ties and tribal ties, allows one to control their own labor and earn an income.

The Tribal Business Structure Handbook published by the Department of the Interior gives guidelines for economic development in its various business forms (2008). In addition to a business model, when business is conducted on a tribe's trust land, as a sovereign nation they 
are exempt from paying state sales tax and pay no corporate tax to the state or federal government (2008). Business entities, such as corporations, can be formed under tribal law, state law or federal law with the tribe's choice of law and the entity that is formed having consequences on issues relating to tax, financing, and sovereign immunity (2008). The tribe, because it is a sovereign nation, can form a government entity to perform business functions (2008).

Oklahoma has a very high concentration of Native American people in comparison to the rest of the United States. According to the 2010 census, the American Indian population was highly concentrated (constituting 8 percent or more of the total county population) in 55 Oklahoma counties (www.census.gov/prod/cen2010/briefs/c2010br-10). For those who claimed American Indian alone in 2010, Arizona, California, and Oklahoma were the three states with the largest shares (www.census.gov/prod/cen2010/briefs/c2010br-10). Concurrently, the amount of tribal trust land, Indian land held in trust by the federal government is present in the state. The 1980 census counted 86,172 acres of tribal trust land and 1,136,162 acres of individual trust land in Oklahoma (www.census.gov/prod2/decennial/documents/1980/1980censusofpopu80211unse_bw).

Having trust land may not lift you out of poverty, however having a business model with beneficial tax laws can create access to income and jobs for a marginalized population, while growing the wealth of the tribe enormously.

Stilwell, Oklahoma is now a town with more than 30 percent of families living in poverty, but the Cherokee Tribe, which brings in 400 million dollars annually at its nine casinos, provides free health care, dental care and other social services to improve the lives of the Cherokee in Green Country. Gambling revived the economy of the Cherokee Nation, but tribal members often live in Oklahoma's rural towns that statistically have higher concentrations of poverty. Federal statistics show that in the year 2000, the Oklahoma Cherokee per capita income was $\$ 9,570$ while the Oklahoma average was $\$ 24,605$ (Bonvillain, 2017). In Stilwell, Oklahoma's poorest town, 32.7 percent of residents lived below the poverty line. Less than 75 percent of Stilwell's adult population had a high school diploma, much lower than the 86.4 percent of adults statewide who had graduated high school (www.msn.com/enus/money/generalmoney/americas-poorest-towns-state-by-state/ar-

BBkW5UI\#image $=B B k T d D O \mid 14)$. Oklahoma's small towns have high concentrations of poverty and jobs created by tribes fill a need in small towns with low economic development and high Native American populations.

The cultural anthropologist, Gordon Macgregor, who did field work on the Pine Ridge Reservation of the Sioux tribe, documented the destruction of a viable way of life when the tribe was ill advised by an Indian agent to sell their cattle and begin farming wheat (Debo, 1970). The demand and value for wheat would not stay high forever and the Indians did not have the capital or experience to operate the agricultural equipment that wheat farming requires (Debo, 1970). Indians began leasing their individual allotments they had received in 1916 to white farmers, but when the price of wheat decreased and the land went back to cattle, the Indians could not regain control of the land (Debo, 1970). The poverty and high suicide rates on the Pine Ridge Reservation are still a serious social problem.

The precarity of farming increased with the onset of the Great Depression and the Dust Bowl, five years of wind and drought, dropped farm commodity prices to disastrous levels, with the gross income of all Oklahoma farm production, both crops and livestock, dropping from \$314 $\begin{array}{lllllll}\text { million } & \text { in } & 1929 & \text { to } & \$ 115 & \text { million } & \text { in }\end{array}$ 
(www.okhistory.org/publications/enc/entry.php?entryname=FARMING). The change to mechanized farming by tractor caused the demand for labor to decline, rural populations declined, and land became concentrated in fewer and fewer hands (Bodley 302). Farming fruits and vegetables in addition to the traditional crops of wheat and cattle brings diversity if one crop fails. The precarity of wheat or cattle farming when the price falls, can be economically devastating, as happened for the Sioux. Congress and Franklin D. Roosevelt enacted the New Deal to help America's farmers by paying government subsidies to farmers who would reduce the amount of land they were farming in order to increase commodity prices according to the law of supply and demand. A very small percentage of Oklahomans live on farms now, but a culture of hard work, cohesive family life, and practicality are some of the traits that are incorporated into the lives of modern Oklahomans now (www.okhistory.org/publications/enc/entry.php?entryname=FARMING).

\section{TRIBAL AUTONOMY}

Tribal autonomy in Oklahoma's Green Country has its beginnings in the southeastern United States when the tribal towns were separate groups who became culturally and linguistically connected to the Muscogee (Creeks). The Cherokee occupied land on the Tennessee River, while the Muscogee (Creeks) lived south of them on the Coosa and Tallapoosa Rivers. The leaders of the Muscogee (Creek) Nation chose to relocate their tribe to land between the North Fork of the Canadian River and the Arkansas and Verdigris Rivers creating a similar neighbor relationship that they had with the Cherokee in the southeastern United States. Anthropologically, both tribes are categorized as "river Indians" who historically foraged and practiced horticulture along water ways.

Further up the Arkansas River from the Cherokee Nation is the Muscogee (Creek) Nation. The Arkansas River is a major water source for Green Country and the Cherokee Nation and other of the Five Civilized Tribes own parts of the Arkansas Riverbed from bank to bank (Clark, 2009). Annual rainfall amounts drop in the flat prairie lands in the western part of Oklahoma, with decreasing humidity along the New Mexico and Colorado borders. For this reason, Native American small businesses switch away from farming to other ways of generating profits.

Thlopthlocco (pronounced rup-rakko), the Muscogee (Creek) word for "lily pad" is one of three tribal towns of the former Muscogee (Creek) Confederacy now headquartered in Okemah, Oklahoma (Clark, 2009). Thlopthlocco was a "red" or war faring town among the "upper creeks", who lived on the upper Alabama River further north from the "lower Creeks", while the Cherokee resided below the Tennessee River. The area was surrounded by three groups of Europeans, the English, Spanish, and French, and was known as The Southern Theater of Conflict at the beginning of the eighteenth century. Traders' paths crossed through the land occupied by the Five Civilized Tribes. European and American incursions into their region both altered their lifeways and led to migration (Clark, 2009). The upper and lower Muscogee (Creeks) dwelled in forty towns that made up the Creek Confederacy until it was dissolved in the 1830's and the Thlopthlocco Indians removed into Indian Territory with other Creeks and the related tribal towns (Clark, 2009).

The Muscogee (Creek) tribal town of the Thloplocco tribe runs a casino, smoke shop, and cabinet making business on a small amount of tribal trust land, where agriculture is not a possible business venture. The town lies on the western side of the Arkansas River where the topography in the state turns to flat prairie land. Their headquarters is in the small town of Wetumka, with a 34 percent Native American population (www.city-data.com/city/WetumkaOklahoma.html\#b). In 1936, the Oklahoma Indian Welfare Act allowed the tribal town to obtain a federal charter and as a recognized tribe could access Individual Indian Money or IIM 
account funds held in trust by the Bureau of Indian Affairs (Clark, 2009) In 1977, the town bought 120 acres of land, placing it into trust, and eventually establishing a casino on the land (Clark, 2009). In 1989, a BIA ruling allowed the tribe to receive further funding under The Indian Self-Determination and Education Assistance Act of 1975 (Clark, 2009).

Farming and crafting as choices of occupation had a larger proportion of American Indians (www.census.gov/prod/cen1990/wepeople/we-5). The Thlopthlocco tribe has a cabinet business and this type of craft business that requires wood working and carving is related to their early cultural customs of planking tree bark for use in housing construction and bending bows for hunting tools. The leadership of the town is serving both a governing and business making role. The duty of the Thloplocco Business Committee is to promote the general welfare of the members of this town and to carry out the provisions and purposes of the Constitution and By-laws of the Thlopthlocco Tribal Town. The Business Committee has the power to appoint subordinate committees and representatives, to transact business and otherwise speak or act on behalf of the 650 enrolled members of the town on all matters (http://tttown.org/gov.html).

\section{CONCLUSION}

Tribal autonomy between the neighboring Cherokee Nation and the Muscogee (Creek) Nation while being historically fixed in geography, culture and language is more actively negotiated and constructed by on-going economic development. Bodley's idea of a Native American small business model is not only applicable to current economic development in Oklahoma, but also emphasizes the importance of culture in modern economy. As tribal wealth soars with impersonal casino cash, the small business model allows for economic diversity, artistic expression and comradery.

\section{BIBLIOGRAPHY}

Bodley, John. (2017). Cultural Anthropology: Tribes, States, and the Global System. $6^{\text {th }}$ Edition. New York: Rowman and Littlefield.

Bonvillain, Nancy. (2017). Native Nations: Cultures and Histories of Native North America. $2^{\text {nd }}$ Edition. New York: Rowman and Littlefield.

Clark, Blue. (2009). Indian Tribes of Oklahoma: A Guide. Norman: University of Oklahoma Press.

Coody Cooper, Karen. (2016). Oklahoma Cherokee Baskets. Charleston: The History Press.

Debo, Angie. (1970). A History of the Indians of the United States. Norman: University of Oklahoma Press.

Halperin, Rhoda. (1994). Cultural Economies: Past and Present. Austin: University of Texas Press.

Oklahoma Historical Society. [Online] at www.okhistory.org/publications/enc/entry.php?entryname=FARMING, accessed May 27, 2018

U.S. Census Bureau. (1980). [Online] at www.census.gov/prod2/decennial/documents/1980/1980censusofpopu80211unse_bw, accessed May 27, 2018.

U.S. Census Bureau. (1990). [Online] at www.census.gov/prod/cen1990/wepeople/we-5, accessed May 26, 2018.

U.S. Census Bureau. (2010). [Online] at www.census.gov/prod/cen2010/briefs/c2010br-10, accessed May 26, 2018.

U.S. Department of the Interior, Office of Indian Energy and Economic Development. (2008). [Online] at www.irs.gov/pub/irs-tege/tribal_business_structure_handbook, accessed May 26, 2018.

Wetumka, Oklahoma. [Online] at www.city-data.com/city/Wetumka-Oklahoma.html\#b, accessed May 28, 2018. 